\title{
Levels Of Heavy Metals In Ground Water From Abokobi Landfill Site In Ghana
}

\author{
Boakye Sandra* ${ }^{1}$, Jonfia-Essien William ${ }^{2}$, Otu Solomon Ayeboafo ${ }^{1}$, \\ Anoumba Vouma Maixant Junior ${ }^{1}$ \\ ${ }^{1}$ Radford University College. Department of Applied Science. P.O.BOX CT 2837 Cantoments Accra Ghana; \\ ${ }^{2}$ Quality Control Company Ltd, (COCOBOD). P. O. Box M54. Accra;
}

\begin{abstract}
A study was undertaken to determine the concentrations of heavy metals in the ground water from landfill leachiest in Abokobi, a suburb of Accra. Nine wells were excavated from the landfill site and the concentrations for heavy metal such as cadmium, arsenic, lead, zinc, copper, chromium, nickel and iron were monitored using wet digestion technique. $\mathrm{HCl}$ and $\mathrm{HNO}_{3}$ were used followed by atomic absorption spectrophotometry. The heavy metals were quantified using external calibration with standards. Copper had the highest mean concentration of $1.22 \mathrm{mg} / \mathrm{l}$ in well (3). This is below the maximum admissible and desirable limit set by the World Health Organization (WHO), an international organization. Chromium recorded the minimum mean concentration of $0.002 \mathrm{mg} / \mathrm{l}$ and this was found in wells 2,3 and 5. Generally the study revealed that $94.5 \%$ of water samples had mean concentrations below the WHO maximum admissible and desirable limit.
\end{abstract}

Keywords: Heavy metal: Groundwater: Landfill: World health organization: Wet digestion

\section{Introduction}

Water is one of the basic needs that support life (Vanloon and Duffy 2005) and is obtained from natural sources including ground water (McMurry and Fay 2004, Mendine 2005). It is estimated that 780 million people lack access to improved drinking water (WHO and UNICEF, 2012) especially in underdeveloped countries. The world is facing challenges in meeting rising demands of clean water as the available supplies of freshwater are depleting due to excessive droughts, population growth, more stringent health based regulations and competing demands from a variety of users (USEPA 1998b, 1999, US BRSNL 2003). On the global scale human activities have resulted in surface and groundwater pollution by a variety of contaminants including heavy metals (Oguzie et al., 2002, Ipinmoroti 1993, Lee et al, 2001, Vidal et al., 2000, Moon et al., 1994, Speir et al., 2003, Razo et al., 2004). Although trace amount of some heavy metals are required by living organisms, excess amount of these metals can be detrimental to life (Berti and Jacobs, 1996; Akhilesh et al., 2009). The solubility of heavy metals in groundwater is largely controlled by $\mathrm{pH}$, amount of metal and cation exchange capacity (Martinez and Motto, 2000), organic carbon content, oxidation state of mineral as well as redox potential of the system (Sherene 2010).

Heavy metal contamination has to be given attention since they are toxic even at low concentrations leading to bioaccumulation and biomagnifications in food chain (Marcovecchio, et al., 2007). Routine monitoring of heavy metal in water is essential to determine the levels and devise strategies to minimize contamination, in order to reduce risks to human health.

\subsection{The study area}

\section{Methodology}

Abokobi is a small town and is the capital of Ga East district Assembly, a district in the Greater Accra region. It is located $30 \mathrm{~km}$ from Accra, off the Adenta-Aburi highway and has a projected population of about 2,089. Abokobi garbage dump is about 800 square-meters. The geology of Abokobi is covered by Acrisols which is a type of soil that is characterized by a subsurface accumulation of low activity clays and low base. 


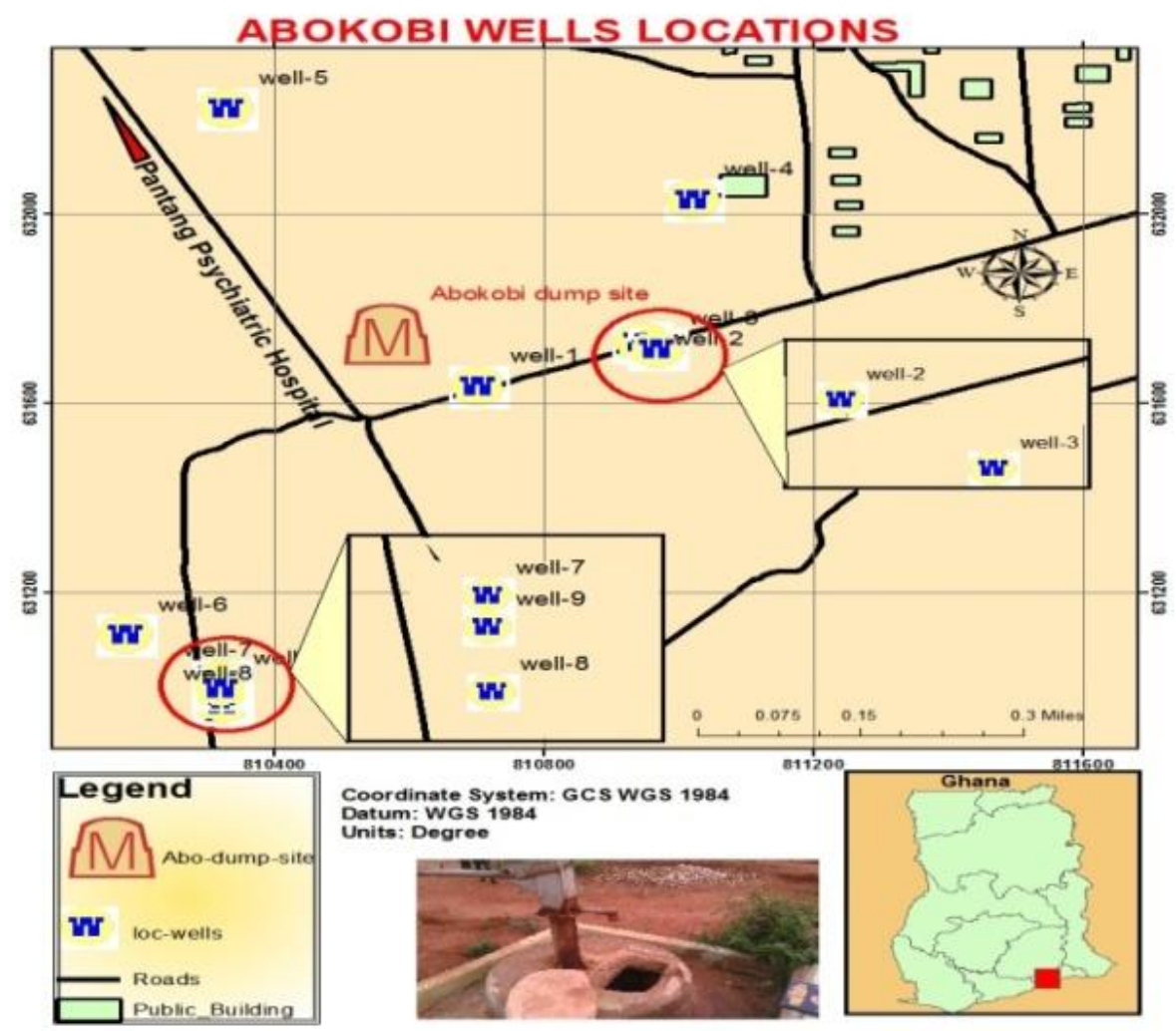

Figure 1: Abokobi well locations from land fill site

\subsection{Reagents and apparatus}

Hydrochloric acid and nitric acid were analytical grade from BDH England, hydrogen peroxide was analytical grade from MERCK Darmstadt, Germany. deionised water, certified calibration standards(BDH England), string and fishing weights, water level indicator (Xi'an Gavin china), $250 \mathrm{ml}$ plastic bottles, flame atomic absorption spectrophotometer (Perkin Elmer $5100 \mathrm{PC})$, Whatma4 filter paper $(0.45 \mu \mathrm{m})$, Ph meter, conductivity meter and temperature probe (vernier software and technology).

\subsection{Determination of $p \mathrm{H}$, Electrical conductivity and temperature}

The electrical conductivity electrode was calibrated using sodium chloride solution of $12880 \mu \mathrm{S} / \mathrm{cm}$. It was rinsed with deionised water and immersed into $50 \mathrm{ml}$ of the water sample. The electrode was slowly moved in a circle for one minute until the digital readout stabilized. The probe was placed in the samples and the meter set to measure temperature. The process was repeated three times for all other water samples. For $\mathrm{Ph}$ measurements the electrode was calibrated with sodium chloride buffer solution at ph of 4.0, 7.0 and 9.0 respectively. The electrode was rinsed with deionised water and then immersed into $50 \mathrm{ml}$ water samples. Measurements were allowed to stabilize and recorded.

\subsection{Sampling}

The study was conducted between February and March 2015. Water samples were taken from nine wells within the sampling area beginning from the least suspected contaminated area. Prior to sample collection, all bottles were washed with detergents, dilute nitric acid and distilled water and dried in an oven. Water samples were collected using a rubber bucket tied to a rope. About $5 \mathrm{~L}$ of bulk sample was collected from all the nine wells in a large plastic bowl after agitation of water to obtain a homogenous sample. Before taking the water samples, the $250 \mathrm{ml}$ plastic bottles were rinsed three times with the water to be collected. Water samples were transferred into the sterilized $250 \mathrm{ml}$ plastic bottles. About $2 \mathrm{ml}$ of $10 \% \mathrm{HNO}_{3}$ was added to each bottle as a preservative (Singh et al., 2010). The water samples were labeled and kept in an ice chest and then transported to the laboratory for storage in a refrigerator at about $4{ }^{\circ} \mathrm{C}$ before analysis.

\section{5 Laboratory analysis}

The water samples were digested using concentrated nitric acid according to Zhang (2007). $5 \mathrm{ml}$ of the digested sample was filtered through a Whatman filter paper $(0.45 \mu \mathrm{m})$ and diluted to $100 \mathrm{ml}$ with deionised water and stored at $4{ }^{\circ} \mathrm{C}$ for analyses. 


\subsection{Preparation of standards}

Mixture of standard solution of selected metals (MIX 1) was prepared for $\mathrm{Zn}, \mathrm{Cd}, \mathrm{Cu}$ and $\mathrm{Cr}$ of concentration $1000 \mathrm{mg} / \mathrm{l}$ by dissolving their high purity metal salts in $0.5 \% \mathrm{HNO}_{3}$. Serial dilutions were made from stock solution to produce calibration standards of concentrations $0.2,0.4,0.6$ and $0.8 \mathrm{mg} / \mathrm{l}$ respectively which were labeled as standard (MIX 1, MIX2, MIX 3 and MIX 4)

Table 1: Results of concentrations of heavy metals calibration standards

\begin{tabular}{|l|l|l|}
\hline STANDARD & COMCENTRATION mg/l & ABSORBANCE \\
\hline MIX 1 & 0.2 & 0.025 \\
\hline MIX 2 & 0.4 & 0.049 \\
\hline MIX 3 & 0.6 & 0.073 \\
\hline MIX 4 & 0.8 & 0.995 \\
\hline
\end{tabular}

\subsection{Instrumental analysis}

The concentrations of $\mathrm{Cu}, \mathrm{Zn}, \mathrm{Cr}$ and $\mathrm{Cd}$ were determined with atomic absorption spectrophotometer (Perkin Elmer 5100 PC) using standard guidelines by APHA, AWWA, WEF 2001. A calibration curve was constructed and the concentration equivalent to the absorbance of the sample was read from the curve and recorded accordingly.

\subsection{Quality assurance}

Blanks were prepared and carried throughout the entire sample preparation and analytical process to determine whether samples were contaminated. Replicate samples were used to determine precision of results. Samples were spiked with $0.2,0.5$ and $1.0 \mathrm{mg} / \mathrm{l}$ of standard MIX solution to determine the recovery.

Recovery $=\frac{\text { Amount of analyte recovered }}{\text { Amount of analyte spiked }} \times 100$

\section{Results And Discussion}

Physical parameters of ground water samples as $\mathrm{p} \mathrm{H}$, conductivity and temperature were conducted on site to determine the stability of nine water samples after purging. The results obtained are shown in table 1 below. Statistical analysis was carried out using IBM statistics 2015 software. The ph ranged between 6.3 to 7.0 and recorded for wells 3 and 8 . The mean electrical conductivity measurements ranged between $950-1410 \mu \mathrm{S} / \mathrm{cm}$ for wells 8 and 5 respectively. The maximum temperature of $35.2{ }^{\circ} \mathrm{C}$ for water was recorded for well 3 and the minimum temperature of $28.8^{\circ} \mathrm{C}$ was recorded for well 8 (Table 2).

Table 2: Comparison of physical parameters of groundwater samples with WHO standards

\begin{tabular}{|l|l|l|l|}
\hline LOCATION & MEAN $\mathbf{p ~ H}$ & MEAN ELECICAL & MEAN \\
& & CONDUCTIVITY $\boldsymbol{\mu S / c m}$ & TEMPERATURE $^{\circ} \mathbf{C}$ \\
\hline WELL 1 & 6.7 & 1400 & 31.8 \\
\hline WELL 2 & 6.5 & 1000 & 29.5 \\
\hline WELL3 & 6.3 & 1230 & 35.2 \\
\hline WELL 4 & 6.8 & 1020 & 34.0 \\
\hline WELL5 & 6.5 & 1410 & 33.5 \\
\hline WELL 6 & 6.7 & 1305 & 29.3 \\
\hline WELL 7 & 7.5 & 1200 & 30.4 \\
\hline WELL 8 & 7.0 & 950 & 28.8 \\
\hline WELL9 & 6.8 & 1050 & 31.5 \\
\hline WHO LIMITS(2011) & $6.5-8.5$ & 500 & \\
\hline
\end{tabular}

The Ph of soil and water affects the migration of heavy metals in the environment. Acidic environment favour the mobility of heavy metal by increasing the proton concentration, rate of desorption and solubility. However alkaline $\mathrm{p} \mathrm{h}$ lowers the migration of ions in water by enhancing the adsorption of heavy metals in water (Sherene, 2010).

Organic matter is important for the retention of metals by soil solids, thus decreasing mobility and bioavailability. For well 1 mean $\mathrm{p}$ h was 6.7 ( Table 2) This accounts for the high concentration of cadmium in water from well 1 . However the lower concentrations of the other metals are attributed to texture, structure and porosity of clay soil (acrisol) which has the capacity to retain most heavy metals than sandy soil. The low temperature of water from well 1 affected the migration rates of most heavy metals in solution. When the temperature rises the metal mobility in the soil solution and water increases. Competition between ions can have a marked effect on heavy metal ion sorption by soils. For instance the presence and competitiveness of Cr (III) in a multiple ion mix will greatly reduce the amount of $\mathrm{Pb}^{2+}$ sorbed, thereby drastically increasing their mobility and potential for transport to ground water. 
Karathanasis (2000) reported that, most heavy metals are generally considered relatively immobile in sub surface soil environment. However, under certain condition their mobility may be accelerated by potential contributions by mobile colloidal particles acting as metal carriers or facilitators to ground water. The presence of colloids increases the transport of both soluble and colloid adsorbed metal fraction. Colloid mediated transport increased with colloid surface charge, $\mathrm{pH}$, organic carbon and soil macro porosity. Microbial degradation of heavy metals is enhanced when they are converted to organic form. The microbes digest the organic form of heavy metals thereby enhancing their mobility in groundwater.

The mean concentration of cadmium in the nine wells was below the WHO limits of $0.03 \mathrm{mg} / \mathrm{l}$ with exception of wells 1 and 4 (Table 3). In particular Cadmium is known to form relatively stable $\mathrm{Cl}^{-1}$ complexes, which greatly influences the mobility of cadmium in water. Other geological factors that account for an increase in cadmium concentrations in well 1 and 4 include $\mathrm{Ph}$, soil texture, structure, porosity, organic matter content and temperature of groundwater. According to Hanaa et al., (2000) cadmium occurs naturally in rocks and soils and enters water when there is contact with groundwater. Moreover, it may be introduced through anthropogenic sources. Conversely the results by Haileslassie and Gebremedhin (2015) revealed that concentrations of cadmium in groundwater were high relative to the recommended values of cadmium in drinking water. In another survey conducted by Reddy et al., 2012 in India, the minimum and maximum concentrations of cadmium were 0.012 to $0.051 \mathrm{mg} / \mathrm{l}$ respectively which were slightly higher than results obtained in this study. The high content of cadmium in different water samples is attributed to the fact that cadmium containing products are rarely re-cycled, but frequently dumped together with house hold waste causing pollution.

Table 3: Results of heavy metal concentrations in ground water samples from nine wells in Abokobi (mg/l)

\begin{tabular}{|l|l|l|l|l|l|}
\hline WELL & CONCENTRATION PPM & $\mathrm{Cu}$ & $\mathrm{Cd}$ & $\mathrm{Zn}$ & $\mathrm{Cr}$ \\
\hline 1 & MEAN & 0.907 & 0.115 & 0.006 & 0.009 \\
\hline & SD & 0.040 & 0.168 & 0.001 & 0.006 \\
\hline 2 & MEAN & 1,027 & 0.003 & 0.007 & 0.002 \\
\hline & SD & 0.064 & 0.001 & 0.001 & 0.001 \\
\hline 3 & MEAN & 1.217 & 0.003 & 0.006 & 0.002 \\
\hline & SD & 0.029 & 0.001 & 0.005 & 0.001 \\
\hline 4 & MEAN & 0.873 & 0.045 & 0.007 & 0.012 \\
\hline & SD & 0.025 & 0.001 & 0.001 & 0.015 \\
\hline 5 & MEAN & 0.850 & 0.004 & 0.006 & 0.002 \\
\hline & SD & 0.075 & 0.001 & 0.001 & 0.001 \\
\hline 6 & MEAN & 0.990 & 0.005 & 0.007 & 0.004 \\
\hline & SD & 0.101 & 0.001 & 0.001 & 0.001 \\
\hline 7 & MEAN & 0.616 & 0.003 & 0.009 & 0.005 \\
\hline & SD & 0.465 & 0.001 & 0.001 & 0.001 \\
\hline 8 & MEAN & 0.663 & 0.006 & 0.006 & 0.005 \\
\hline & SD & 0.099 & 0.001 & 0.001 & 0.001 \\
\hline 9 & MEAN & 0.710 & 0.006 & 0.009 & 0.004 \\
\hline & SD & 0.040 & 0.001 & 0.001 & 0.002 \\
\hline WHO LIMIT(2011) & & 2.000 & 0.030 & 5.000 & 0.050 \\
\hline
\end{tabular}

The mean concentrations of chromium in water samples from the nine wells were below the WHO limits of $0.05 \mathrm{mg} / \mathrm{l}$.(Table 3). Research indicates the presence and competitiveness of $\mathrm{Cr}$ (III) in a multiple ion mix will greatly reduce the amount of $\mathrm{Pb}^{2+}$ adsorbed, thereby drastically increasing their mobility and potential for transport to ground water (Sherene, 2010). This accounts for low levels of chromium and elevated levels of lead in water. Also chromium is present in small quantities in nature and there are no fresh inputs of chromium into the environment by human activities. Singh et al. (2010) reported equally low levels of Chromium $(0.05$ $\mathrm{mg} / \mathrm{l}$ ) in wastewater. Conversely, a study by Jameel et al., 2012 showed high levels of chromium in water samples.

In this research, the levels of copper in all the nine wells were below the WHO allowable limit of 2.0 $\mathrm{mg} / \mathrm{l}$ irrespective of low $\mathrm{pH}$ and increased temperatures. This is explained by the competition between metal between lead and copper as well as copper and nickel. This accounts higher levels of nickel and lead in water samples than the copper. A study by Jameel et al., 2012 revealed lower amount of $\mathrm{Cu}$ content was found in water samples. Conversely, it has been reported that levels of copper $(0.37 \mathrm{mg} / \mathrm{l})$ in waste water from Adis Ababa were higher than WHO guidelines (Weldegebriel et al., 2012).

Levels of zinc water in the nine wells were below WHO limits of $5.0 \mathrm{mg} / \mathrm{l}$ (Table 3). This is explained by high electrical conductivity values for heavy metals causing competition between zinc and calcium ion and lowering the mobility of zinc in water. Research on heavy metals from Ota Nigeria showed lower concentrations of zinc ranging from 0.04 to $0.65 \mathrm{mg} / \mathrm{l}$ (Anake et al., 2014). Results of a study conducted in Palestine by Malassa et al., 2013 showed that the concentration of $\mathrm{Zn}$ was within the allowed WHO limits in drinking water. 


\section{Conclusion}

From this study it can be concluded that $94.5 \%$ of heavy metals analyzed were below the WHO permissible levels for drinking water. Copper recorded maximum mean concentration of $1.22 \mathrm{mg} / \mathrm{l}$ in well 3 whereas the lowest mean concentration of $0.002 \mathrm{mg} / \mathrm{l}$ was detected in wells 2,3 and 5 for chromium. There was a positive correlation for $\mathrm{Ph}$, temperature and conductivity with the concentrations of heavy metals recorded in wells in Abokobi land fill site.

\section{Acknowledgement}

I appreciate very much the involvement of, and support received from Dr William Jonfia Essien and Mr Solomon Otu Ayeboafo for the immense contribution and considerable work done to assist me in this research.

\section{References}

[1]. Abdul Jameel, A., Sirajudeen, J. and Abdul Vahith,R. (2012): Studies on heavy metal pollution of ground water sources between Tamil Nadu and Pondicherry, India. Advances in Applied Science Research, 3: $424-429$.

[2]. Akhilesh J, Savita D, Suman M. Some trace elements investigation in groundwater of Bhopal and Sehore District in Madhya Pradesh, India. J Appl Sci Environ Manag. 2009;13(4):47-50.

[3]. Anake WU, Ehi-Eromosele CO, Siyanbola TO, Edobor-Osoh A, Adeniyi IO, Taiwo OS (2013). Physico-Chemical and Microbial Assessment of Different water sources in Ota, Ogun State, Nigeria. Int.J. Curr. Res. 5(07):1797-1801.

[4]. APHA-AWWA-WEF. (2001). Standard Methods for Examinations of Water and Wastewater, (22nd ed., pp. 4-146). Washington D.C.

[5]. Berti, WR and Jacobs LWP (1996). Chemistry and Phytotoxicity of soil trace elements from repeated sewage sludge application. J Environ Qual 25: 1025 - 1032

[6]. Hanaa, M., Eweida, A \& Farag, A. 2000. Heavy metals in drinking water and their environmental impact on human health. International Conference on Environmental Hazards Mitigation, Cairo University, Egypt, pp. 542-556.

[7]. Ipinmoroti KO.1993. Water quality of shallow wells located close to dumpsite in Akure, Nigeria. Pakistan Journal of Scientific and Industrial Research 36, 137-141

[8]. Karthanasis, A.D. (2 000 ). Mineral controls in colloid mediated transport of metals in su b su rface environments. In: Proc.6 th International conference on biogeochemistry of trace elements Guelph

[9]. Lee C, Chon H, Jung M. 2001. Heavy metal contamination in the vicinity of the Daduk Au-Ag- $\mathrm{Pb}-\mathrm{Zn}$ mine in Korea. Applied Geochemistry 16,1377-1386.

[10]. H. Malassa, M. Al-Qutob, M. Al-Khatib and F. Al-Rimawi, "Determination of Different Trace Heavy Metals in Ground Water of South West Bank/Palestine by ICP/MS," Journal of Environmental Protection, Vol. 4 No. 8, 2013, pp. 818-827.

[11]. Marcovecchio, J.E., S.E. Botte and R.H. Freije, 2007. Heavy Metals, Major Metals, Trace Elements. In Handbook of Water Analysis. L.M. Nollet, 2 Ed. London: CRC Press, pp: 275-311

[12]. Martinez, C. E. and Motto, H. L. (2000). Solubility of lead, zinc andcopper added to mineral soils, Environmental Pollution, 107, no. 1 , pp. $153-158$.

[13]. Mc Murry, J and Fay, R.C, (2004) hydrogen, oxygen and water. In : McMurry Fay chemistry. Hamann, K.P. New Jersey: Person education, $4^{\text {th }}$ edition, pg $575-599$.

[14]. Mendie, U, (2005) The nature of water. In : the theory and practice of clean water production for domestic and industrial use. Lagos, L. Medals publisher, pg 1-21.

[15]. Moon CH, Lee YS, Yoon TH. 1994. Variation of trace $\mathrm{Cu}, \mathrm{Pb}$ and $\mathrm{Zn}$ in sediment and water of an urban stream resulting from domestic effluents. Water Research 28,985-991

[16]. Oguzie EE, Agochukwu IB, Onuchukwu AI, Offem JO.2002. Ground water contamination: A simulation study of buried waste metallic contaminant penetration through the aquifers. of the Chemical Society of Nigeria 27,82-84.

[17]. Razo I, Carrizales L, Castro J, Díaz Barriga F, Monroy M.2004. Arsenic and heavy metal pollution of soil, water and sediments in a semi arid climate mining area in Mexico. Water, Air and Soil Pollution 152,129-152.

[18]. Singh A., Sharma R. K., Agrawal M. and Marshall F. M. (2010). Risk assessment of heavy Metal toxicity through contaminated vegetables from wastewater irrigated areas in Varanasi, India. Tropical Ecologhcal Issue 51. 2: 375-387.

[19]. Sherene .T(2010).Mobility and transport of heavy metals in polluted soil environment. Biological Forum - An International Journal, 2(2): 112-121

[20]. Speir TW, Van Schaik AP, Percival HJ, Close ME, Pang L. 2003. Heavy metals in soil, plants and ground water following high-rate sewage sludge application to land. Water Air and Soil Pollution 150,319-358

[21]. Reddy, V.M., Babu, K.S. Balaram, V. and Satyanarayanan, M. (2012). Assessment of the effects of municipal sewage, immersed idols and boating on the heavy metal and other elemental pollution of surface water of the eutrophic Hussainsagar Lake (Hyderabad, India). Environmental Monitoring and Assessment184,1991-2000.

[22]. Valoon, G.W, and Duffy, S.J, (2005) The hydrosphere. In: environmental chemistry, a global perspective; $2^{\text {nd }}$ edition, Newyork, Oxford university press, pg 197-21

[23]. Vidal M, Melgar J, Lopez A, Santoalla MC.2000. Spatial and temporal hydrochemical changes in ground water under the contaminating effects of fertilizers and wastewater. Journal of Environmental Management 60,215-225

[24]. Weldegebriel. Y., Chandravanshi. B. S. and Wondimu. T(2012). Concentration levels of metals in vegetables grown in soils irrigated with river water in Addis Ababa, Ethiopia. Ecotoxicology and environmental safety 77, 57-63

[25]. World Health Organization and UNICEF (2012). Progress on Drinking Water and Sanitation: 2012 Update. United States: WHO/UNICEF Joint Monitoring Programme for Water Supply and Sanitation 